\title{
Channel dynamics and hydraulic geometry of two tropical deltaic catchments in Southern Nigeria
}

\author{
Augustus O. Aisuebeogun'1, Ifeanyichukwu C. Ezekwe² \\ ${ }^{1}$ Department of Geography and Environmental Management, Niger Delta University, Nigeria \\ ${ }^{2}$ Department of Geography and Environmental Management, University of Port Harcourt, Nigeria, \\ e-mail: clinton.ezekwe@uniport.edu.ng
}

\begin{abstract}
This paper attempts to explain the channel processes and dynamics of two river systems running through a rapidly urbanizing humid tropical deltaic environment with visible threats from industrialization and pollution. Hydraulic processes and parameters were compared with established power function relations for hydraulic geometry and it was discovered that the fundamental relations between channel-geometry dimensions, velocity, and flow can be expressed for the catchments. Ten gauging stations in each catchment were studied and results showed that the studied catchments adjust their geometry to changing discharges. High values of coefficients of determination among variables indicated that much of the downstream variation in channel width to depth ratio can be accounted for by changes in discharge. Also in this study the width/depth ratio (F) was found to be related to the percentage of silt + clay $(\mathrm{M})$ in channel perimeter and that downstream hydraulic-geometry relations are in general agreement with previously published hydraulic and channel adjustment data.
\end{abstract}

Key words: Catchment morphometry; hydraulic processes; Sombreiro River; New Calabar River; Niger Delta

\section{Introduction}

In the future, the dependence of humans on large river systems will increase because of growing populations. Human disturbance of different types of river systems at different scales is a consequence of the perceived needs of catchment populations without due consideration for the 'needs' of the river itself. Most river systems provide critical ecosystem sources to large populations and considerable pressure is exerted by population on these river systems through water abstraction for irrigation, pollution through industrial and urban expansion, as well as reduction in connectivity and alterations of hydrologic regimen by the construction of dams, barrages and related engineering structures. River engineering should be based on a priori knowledge of river science for building harmonious 'human-river' relationships (Tandon 2012); and this is what is lacking in most developing areas of the world due to the absence or paucity of 'river data' that would have assisted in regional development planning or river management processes.

The complexities in river systems, as well as their similarities under diverse settings, pose a real challenge for study. Underlying these complexities is an assortment of interrelated variables that determines the dimension, pattern, and profile of the present-day river. The resulting physical appearance and character of the river is a product of adjustment of its boundaries to the current stream flow and sediment regime (Rosgen 1994). Observations from previous studies show that river channel and flood-plain dynamics and morphology are affected by interactions between flow, sediment, and standing and entrained wood, some of which likely involve time frames similar to 200500-year flood-plain half-lives (O'Connora et al. 2003).

Therefore effective stream or river management planning is governed by an understanding of river morphology and channel processes. Morphological diversity is one of the basic parameter to define river health because a river with significant morphological variability is characterized by higher biodiversity and better ecosystem. Detailed morphological assessment also enhances the understanding of channel processes, its natural capability to adjust and depicts the inherent character of the river and possible response to human impact. It provides the basis to develop ecosystem based management for the river (Bawa et al. 2012).

The morphology of a river channel is a product of the erosive potential of the river and the resistance forces 
of the valley floor materials. Over time, rivers develop a dynamic equilibrium between their channel and normal flow. The form of this channel affects the flow of water in it and, through erosion and deposition, the flow modifies the form. River channels vary greatly in cross-sectional size and shape but are usually bounded by defined banks which separate the channel from the floodplain or valley side. The bankfull dimensions of a channel combine with the velocity of the flow to determine discharge. In general, discharge increases with increasing catchment area, and the width and depth of the channel and the velocity of the water also increase downstream. Channel dimensions adjust through erosion and deposition and the shape of the cross-section is described as a ratio of channel width to depth. The depth of flow in a channel is directly proportional to the force which the water exerts on the bed and to its ability to transport sediment. Any operation which alters the width-depth ratio alters the channel capacity for sediment transport and increases the likelihood of future instability (Leys 1997).

Processes operating in a drainage basin include runoff (channeled and unchannelled flows) sediment and solute flows and other ancillary forces like slope and hydrophysical processes. Application of morphometric analysis is essentially a descriptive technique and does not supply ready answers to how processes actually shape present day landscapes because fluvial processes have complex interrelationships with basin morphology of stream channels.

In a given reach, a river has the potential both to scour material from its bed and banks and to transport material which has been brought into the reach from upstream. The rate of transport is determined partially by channel gradient, discharge and sediment size. The sediment moves either as bedload where the coarse material rolls, slides or bounces along the bed, or as suspended load where fine particles are moved in suspension or become dissolved in solution. Bank erosion is one of the principal means of sediment supply to streams. A sudden reduction of this supply through, for example, revetment of the banks, will produce an abrupt change in the sediment and water balance and may mean that the river will seek to erode more sediment from its bed to compensate. A gradual reduction of the sediment supply for example, through reestablishment of riparian vegetation, is more in keeping with the timescale of natural channel processes and will lead to a gradual change in channel behaviour (Leys 1997).

Hydraulic geometry relations and hydraulic models and curves, expressed as well-established power functions, describe the relations between channel geometry, velocity, and flow at a given point on a river (Dudley 2004). Channel Hydraulic geometry relations assist in understanding channel adjustment processes but are limited in their predictive capabilities and require cautious application for such purposes (Simon and Castro 2003). In addition to cross-sectional adjustments, the planform and profile (longitudinal slope) characteristics of a river also adjust to changing water and sediment inputs. Altera- tions in the natural flow regime of any river or stream can result in adjustments to the overall planform (geometry), cross-sectional channel geometry, bed configuration, and channel-bed. These changes in the hydrogeomorphic attributes of a river channel may cascade into degradation of its physical habitat attributes, which are important for aquatic and riparian life (Alexander et al. 2009).

It is therefore very necessary to measure the processes operating in a catchment in order to understand how catchment forms evolve and how they impinge on ecological communities and respond to the influence of man. Without such measurements, ideas, theories and estimates cannot be substantiated and quantitative relationships between form and processes cannot be established (Gregory and Walling 1973).

It is in the light of the above that this paper attempts to explain the channel processes and dynamics of two river systems running through a rapidly urbanizing humid tropical deltaic environment with visible threats from industrialization and pollution. Fluvial processes considered in this study include river discharge; river sediment loads comprising of suspended load and dissolved solids. Measurement of runoff dynamics was limited to channel flow only; and parameters of flow measured included river velocity and stream discharge, both in a downstream direction. Measurement of sediment and solute dynamics involved bedload sampling, river water sampling and sampling of channel perimeter sediment, notably river bank sediments.

The study involved the gathering of primary data, through field measurements in the near absence of secondary data.

\section{Study area}

\section{Hydrology}

This investigation was carried out in the plains and lowlands of the Niger Delta flanks including the Coastal Plains and the Sombreiro-Warri Deltaic Plains of South-southeastern, Nigeria (Figs 1 and 2). The Sombreiro River rises from a broad plain swampy depression that abut the Coastal Plain highs around Izombe in Imo State Nigeria while the New Calabar (Kalabari) River rises from the waters of the swamp basins within the Coastal Plains Sands Formation in the eastern south-south Nigeria and from a maze of effluents and ephemeral streams crossing the homogeneously flat land around Isiokpo and Elele in Rivers State Nigeria (Figs 1 and 2). Catchments were delimited using published maps including 1:50,000 and 1:100,000 topographical maps obtained from the Nigerian Federal Surveys (sheet 320 Ahoada, Degema NE and Ahoada SE).

The New Calabar River was demarcated with the aid of 1:50,000 Degema NE and Ahoada S.E. sheets. The resulting catchment is a second order basin occupying an 


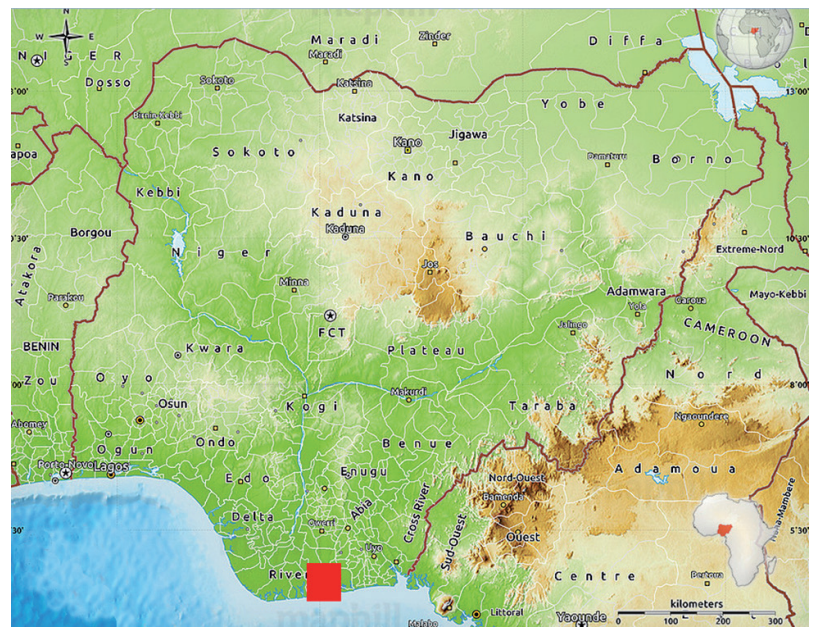

Fig. 1. Map of Nigeria showing study area

area of $208 \mathrm{~km}^{2}$ from its designated catchment mouth of Choba. The Sombreiro catchment on the other hand was delimited with sheet 320 (Ahoada) Nigeria 1:100,000 topographical maps. It is noteworthy, however, that this sheet, like the 1:150,000 equivalent, carries no form lines, perhaps due to the extremely flat nature of the terrain in the study area covered by this catchment.

The Sombreiro has an area of $484 \mathrm{~km}^{2}$ and is at best a unique second order basin from its catchment mouth at Ahoada. The river rises from broad swamps of over $300 \mathrm{~km}^{2}$ around the Izombe-Eziorsu-Egbema axis of South-eastern Nigeria at the boundaries between the Coastal Plain Sands and the Warri-Deltaic Plains and is fed mainly by groundwater recharge from the prolific Coastal Plain aquifers and occasional ephemeral stream run-offs.

The Sombreiro system becomes a fourth order stream in years with extreme flood events when its Nkissa tributary that flows into the Orashi system through the Ebocha area reverses its flow much like the Tonle Sap in Cambodia, making the area of the catchment to include the upper and upper middle reaches of the Orashi River with an area

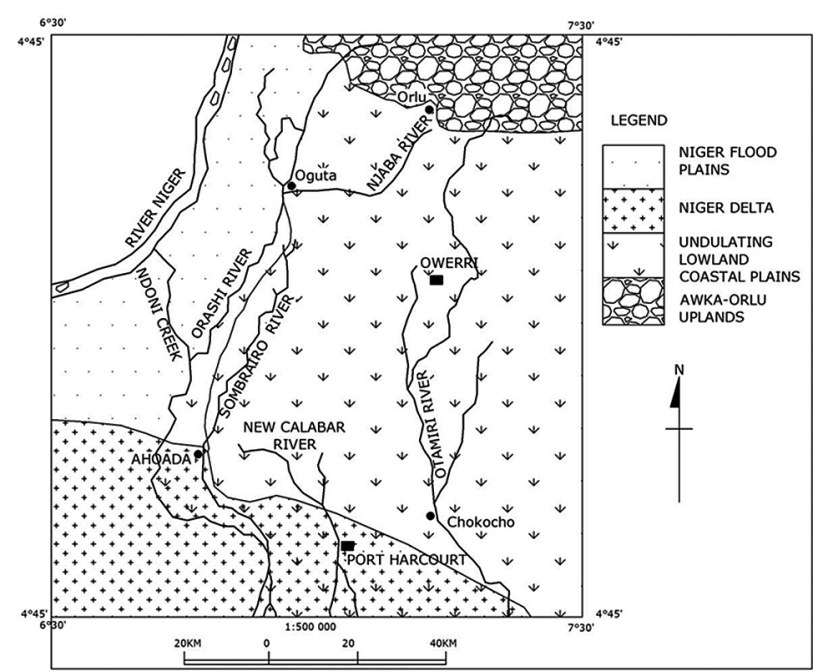

Fig. 2. Geomorphology of study area of about $1,650 \mathrm{~km}^{2}$ to become part of its catchment. The Sombreiro is not a distributary of the River Niger as popularly postulated (Ezekiel et al. 2011) but has a unique quality of flowing through a geological boundary area and having little contribution in terms of surface discharge but contributing immensely to and discharging excess flood water from the Orashi river systems.

\section{Physiography}

The general morphological framework of the study area is within the modern Niger Delta. There has been a cyclic repetition of form, processes and phenomena which have left their mark on the stratigraphy of the study area from Tertiary to Recent times (Short and Stauble 1967, Azeez 1971).

Two main geologic formations are found in the study area; alluvial marine deltaic deposits of Recent age and the Coastal Plain Sands (Benin Formation) of the Miocene-Pleistocene age. The history of the Niger Delta environment since its inception is one of a major regression with a gradual southward off-lap of extensive macro-lenses of sediments. Structurally, the area is characterized by a seaward regional dipping. The formations dip gently south-westward at angles of $1^{\circ}$ to $5^{\circ}$, but no significant structural control on the evolution of the drainage network and surface forms is discernible. The predominant morphology is the Coastal Plain Terrace - which is characterized by gently rolling low-relief landforms that trend to the south and southwest of the study area with reliefs as low as $10 \mathrm{~m}$ in the southernmost mouths of the Sombreiro and New Calabar rivers beyond the Degema and Abonnema areas of Rivers State, Nigeria. Slopes are rarely in excess of $10 \%$ for most of the micro relief of the study area.

\section{Climate, Soil and Vegetation}

The study area is characterized by a transitional equatorial climate where the annual rainfall is greater than $1,200 \mathrm{~mm}$. Rainfall is typically $2,700-3,000 \mathrm{~mm} \mathrm{y}^{-1}$, with annual average temperature range of between $21^{\circ}-28^{\circ} \mathrm{C}$ $\left(70^{\circ}-82^{\circ} \mathrm{F}\right)$ and actual evaporation of about 1,000 millimetres engendering a relative humidity of up to $90 \%$ (Golitzen 2005). There are two distinct wet and dry seasons, a double maxima rainfall in July and September. The wet season lasts for about 8 months (March - October) while the dry season lasts for about 4 months (November - February).

The area also falls within The Cross-Niger Transition Forests which is a part of the tropical moist broadleaf forest ecoregion of south-eastern Nigeria. It is a deltaic lowland massive rain forest and fresh water swamp basin characterized by the ubiquitous presence of the stately oil palm tree (Elaeis guineensis), the Raphia palm, Calamus species and fresh water swamp species noted for its climax ecosystem communities, high biomass productivity levels and an abundance of diverse plant species. The Sombreiro-New Calabar catchment area has three main 
soil types including the deep porous red soils of the coastal plains commonly called 'acid sands'; the deep porous brown soils derived from sandy deposits, and the pale brown loamy alluvial deposits derived from recently deposited materials.

\section{Materials and methods}

Measurements were conducted at ten sites and in each catchment; three different cross-sectional morphologic measurements were done. These are mean depth of channel, river channel width at the bank-full stage (peak flow in October) and valley side slope. Mean depth measurements were accomplished with the aid of an improvised calibrated string with an attached deadweight. At each sampling site, four to six depth readings were taken and then averaged to give the mean depth value for that site. In some sites where possible, values where averaged from dive reading.

Channel width measurements involved the measurement of river water width from one bank to the other. The stage was itself readily identified in the field in accordance with the criterion set out by Morisawa (1976) and Smith and Stopp (1979). Care was taken at ensuring that measurement was done along straight courses of the channel reach in order to avoid the predictable channel patterns and processes at meander bends. A composite profile of width and depth measurements provided the channel cross-sections for each sampling site (cf. Table 1 and 2).

\section{Velocity and Discharge Measurements}

As no secondary data on discharge could be obtained, discharge was measured in the field in the downstream direction. Readings were taken in each of the ten sampling sites with the aid of a river craft. Measurements also included channel mean velocities, mean depth and channel width.

Velocity measurements were accomplished with the use of carefully crafted improvised floats with attached weights after the recommendations of Morisawa (1976) and Smith and Stopp (1979). A correction factor of 0.85 was applied to results to correct for inadequacies (Morisawa 1976, Schumm 1977, Smith and Stopp 1979; Goudie
1981). River width measurements taken from the bankfull stage were also undertaken and discharge was calculated as a product of the river velocity and channel morphologic indices of mean depth and width (cf. Table 1 and 2).

\section{Sediment/Solute Analysis}

Ten water samples were collected from the rivers in a downstream direction for the determination of solute concentrations, the total dissolved solids (TDS) and the hydrogen ion concentration, $\mathrm{pH}$. Sampling was with wash bottles using the depth integrated sampling method (Goudie 1981). Gregory and Walling (1973) observed that the dissolved load of river can originate from several sources including chemical weathering which is the prominent form of weathering in the humid tropics (Faniran 1986). A portable Benchman conductivity meter was used to measure conductivity and $\mathrm{pH}$ of the water samples. Total suspended solids (TSS) and TDS were determined using the gravimetric methods (Martinez et al. 2011). The water samples were filtered and $100 \mathrm{~mL}$ of the filtrate evaporated in a pre-weighed evaporating dish. The increase in mass over that of the empty evaporating dish represents the TDS in $\mathrm{mgL}^{-1}$. Weighing was done using an analytical balance (Mettler 2000 balance) and values derived using:

$$
\begin{gathered}
\mathrm{TDS}\left[\mathrm{mgL}^{-1}\right]=(\mathrm{A}-\mathrm{B}) * 1000 \text { sample volume } \\
\mathrm{mL}
\end{gathered}
$$

where: $A=$ mass of sample + weight of evaporating dish, $\mathrm{mg}, \mathrm{B}=$ mass of evaporating dish, $\mathrm{mg}$.

TSS was also determined using the gravimetric method. Water sample $(100 \mathrm{~mL})$ was evaporated to dryness using a pre-weighed $100 \mathrm{~mL}$ beaker. After evaporation the beakers were placed in desiccators before weighing and values derived using:

$$
\operatorname{TSS}\left[\mathrm{mgL}^{-1}\right]=[(\mathrm{B}-\mathrm{A}) / 100 \mathrm{~mL}] / 100 * 1000 \ldots
$$

where: $\mathrm{B}=$ mass of $100 \mathrm{~mL}$ beaker with evaporated sample, $\mathrm{A}=$ mass of $100 \mathrm{~mL}$ empty tared beaker.

Channel perimeter sediments were collected and analyzed for grain size distribution and results subjected to

\begin{tabular}{|c|c|c|c|c|c|}
\hline \multirow[t]{2}{*}{ Location } & $\begin{array}{c}\text { Width } \\
w\end{array}$ & $\begin{array}{c}\text { Mean depth } \\
d\end{array}$ & $\begin{array}{c}\text { Velocity } \\
v\end{array}$ & $\begin{array}{c}\text { Discharge } \\
\text { Q }\end{array}$ & $\begin{array}{c}\text { Width/Depth Ratio } \\
\text { F }\end{array}$ \\
\hline & \multicolumn{2}{|c|}{$[\mathrm{m}]$} & {$\left[\mathrm{m} \mathrm{s}^{-1}\right]$} & {$\left[\mathrm{m}^{3} \mathrm{~s}^{-1}\right]$} & {$[-]$} \\
\hline Okansu I & 3.00 & 1.24 & 0.16 & 0.60 & 2.42 \\
\hline Okansu II & 6.45 & 1.74 & 0.21 & 2.50 & 3.71 \\
\hline Okansu III & 13.2 & 2.24 & 0.27 & 8.50 & 5.89 \\
\hline Ikiri I & 15.1 & 2.40 & 0.32 & 11.34 & 6.29 \\
\hline Ikiri II & 17.8 & 2.45 & 0.32 & 11.86 & 7.26 \\
\hline Obukegi & 18.2 & 2.50 & 0.29 & 13.60 & 7.28 \\
\hline Ahoada I & 52.5 & 3.55 & 0.42 & 84.80 & 14.79 \\
\hline Ahoada II & 63.1 & 4.17 & 0.45 & 120.00 & 15.13 \\
\hline Ahoada III & 72.0 & 3.97 & 0.45 & 128.14 & 18.14 \\
\hline
\end{tabular}
further calculations and statistical analysis. In this study

Table 1. Sombreiro River Channel Parameters 
Table 2. New Calabar River Channel Parameters

\begin{tabular}{|c|c|c|c|c|c|}
\hline \multirow[t]{2}{*}{ Location } & $\begin{array}{l}\text { Width } \\
\text { w }\end{array}$ & $\begin{array}{c}\text { Mean depth } \\
\text { d }\end{array}$ & $\begin{array}{c}\text { Velocity } \\
\text { v }\end{array}$ & $\begin{array}{c}\text { Discharge } \\
\text { Q }\end{array}$ & $\begin{array}{l}\text { Width/Depth } \\
\text { Ratio F }\end{array}$ \\
\hline & \multicolumn{2}{|c|}{$[\mathrm{m}]$} & {$\left[\mathrm{m} \mathrm{s}^{-1}\right]$} & {$\left[\mathrm{m} 3 \mathrm{~s}^{-1}\right]$} & {$[-]$} \\
\hline \multicolumn{6}{|c|}{ Elele Arm } \\
\hline Elele Alimini I & 21.87 & 2.5 & 0.32 & 25.3 & 8.75 \\
\hline Elele Alimini II & 35.5 & 3.47 & 0.31 & 47.0 & 10.23 \\
\hline Odohua & 55.0 & 4.9 & 0.19 & 50.6 & 11.22 \\
\hline Elibrada & 45.7 & 3.4 & 0.38 & 62.1 & 13.44 \\
\hline \multicolumn{6}{|c|}{ Isiokpo Arm } \\
\hline Isiokpo I & 14.0 & 1.03 & 0.71 & 10.0 & 13.6 \\
\hline Isiokpo II & 24.0 & 2.0 & 0.67 & 16.0 & 12.0 \\
\hline Aluu I & 31.6 & 2.8 & 0.4 & 32.7 & 12.15 \\
\hline Aluu II & 75.86 & 5.4 & 0.45 & 150.0 & 14.05 \\
\hline \multicolumn{6}{|c|}{ Joined Arm } \\
\hline Choba I & 135.6 & 8.5 & 0.5 & 490.0 & 15.95 \\
\hline Choba II & 151.3 & 7.58 & 0.41 & 400.0 & 19.96 \\
\hline
\end{tabular}

only sediment in and around channels were measured. This included bedload type, river bank sediment, river water samples for analysis of their suspended and dissolved solute contents.

Bedload sediment samples were taken with the aid of a metal scoop. A one-meter long metal corer was employed in the sampling of river bank sediment at $0.8 \mathrm{~m}$ depth. This is because concentrations vary in a stream cross-section thereby requiring a representative sample of sediment concentrations in as wide a zone as possible in the channel (Gregory and Walling 1973, Smith and Stopp 1979). River bank and river bed sediments were analyzed by sieve analysis (ASTM 2006). Percentage retained-weight results were plotted on phi (ø) particle size graph sheets and found to be better suited for analysis than the percentage finer plots on semi-log graph sheets using Wentworth's scale. As such, the inclusive graphic measures of Folk and Ward (1957) in phi units were adopted in the analyses of the results. Sediments were further analyzed for their mean, median, sorting, skewness, kurtosis and $\mathrm{M}$ (percent silt and clay) values. The $\mathrm{M}$ values for the catchment have been presented in Table 4 and 5 . Therefore only the inclusive graphic measures of the bed load and river bank sediment are presented in Table 7.

\section{Results and discussion}

\section{Channel Parameters}

According to Alexander et al. (2009), the hydraulic geometry relations use stream-flow discharge-measurements from either individual stream-flow gauging stations (at-a-station geometry) or data from multiple stream-flow gauging stations, common measurement increments, and common periods of record to relate wetted-channel geometry and water velocity to river discharge through a series of empirical models in the form of power functions.

Leopold and Maddock (1953) referred to these models as downstream hydraulic geometry relations. These rela- tions are examined to understand how a stream channel adjusts and accommodates gains of water and sediment with increases in drainage area. These power functions as presented by Leopold and Maddock (1953) are presented as follows:

$$
\begin{gathered}
w=a \mathrm{Q}^{b} \\
d=c \mathrm{Q}^{f} \\
v=k \mathrm{Q}^{m}
\end{gathered}
$$

The variables $w, d$, and $v$ are wetted-channel top width, mean depth, and mean velocity of the cross section, respectively; $a, c, k, b, f$, and $m$ are numerical constants, $b, f$, $m$ are exponents while $a, c, k$ are coefficients which must equal unity (Wohl et al. 2005). Stream channel parameters and hydraulic geometry relations for the two catchments under consideration are reported below.

The Sombreiro River conforms to the general character of tropical streams (Wolman 1955, Dury 1963, Leopold et al. 1964, Ofomata 1974, Smith and Stopp 1979, Thornes 1979) but differed markedly from streams from other climes. For instance, for the United States, rivers of the semi-arid Southwest and Great Plains, Leopold and Maddock (1953) reported averages of 0.26, 0.40, and 0.34 for exponent $b, f$, and $m$, respectively, although these values have been shown to be highly variable depending on regional climate and physiography (Park 1977). It has however been reported that channel width varies approximately in proportion to the square root of discharge (that is $b=0.5$ ) for alluvial rivers (Parker 1979, Parker et al. 2007).

The channel morphologic parameters for the Sombreiro including velocity and discharge increase in a downstream direction in an orderly progressive way because of its unique characteristics referred to earlier and its typical setting and existence in a uniform geologic setting (Table 1). This catchment therefore conforms totally to earlier views expressed on the general downstream increase in width, depth and velocities of tropical streams. 
In Table 2 above the channel parameters of the New Calabar River also show a general downstream increase especially in width, depth and discharge characteristics. Velocity however shows a random pattern, although a general decrease in the downstream direction is observable. This may be a result of the river originating in the Coastal Plain Sands and cascading into the broad slopes of the Recent deltaic setting.

Thus of the two rivers, only the Sombreiro has a highly synchronized and orderly downstream increase in width, depth, velocity and discharge. It has a smaller basin relief $(10.7 \mathrm{~m})$ as well as channel gradient (0.0002). It also has the most comparable figures with earlier (at-a-station measurements) studies (NEDECO 1959, 1961) obtained at the Ahoada gauging station.

\section{Channel Hydraulic Geometry}

\section{The Sombreiro Channel}

Leopold and Langbein (1962) theoretically derived relationships should be recalled as basis for comparing field results. Their downstream relations for width, depth and velocity; where the exponent are $b=0.55, f=0.36$ and $m=0.09$. Wolman (1955) obtained similar results from studies of the Brandywine Creek of Embreeville, Pennsylvania. These exponents when summed up add up to 1.0 a requirement of the continuity principle. The channel hydraulic geometry relations in the study area also showed similar results. The Sombreiro River channel geometric relations indicate a high conformity between empirical observations and theoretical derivation. The following morphology-discharge relations were observed for the river:

$$
\begin{aligned}
& w=3.88 \mathrm{Q}^{0.59} \\
& d=1.41 \mathrm{Q}^{0.22} \\
& v=0.18 \mathrm{Q}^{-0.19}
\end{aligned}
$$

The relationship of each of these factors or variables to discharge is linear as may be observed from figure 4 . The width-discharge relation shows a more rapid change than depth and velocity in a downstream direction, for the channel. Depth-discharge relations indicate a moderate increase in the same direction, with slowest and fastest velocities recorded during field studies at Okansu and Ahoada respectively. Thus the Sombreiro exhibits an efficient downstream adjustment in its morphologic hydrologic relationships. The sum of the exponents of equations 3-5 above satisfies the requirements of the continuity principle (Table 3). The values of $b, f, m$ sum up to 1.0, i.e.: $0.59+0.22+0.19=1.0$. The products of constants $a$, $c, k$ also gives $1.0(3.88 * 1.41 * 0.18=1.0)$

The perfect nature of these values suggest that the river has a normal hydrologic regimen (Morisawa 1976) well adjusted to the channel morphologic variables of width, depth and velocity. They also indicate that in the Sombreiro River the morphologic variables are highly interrelated. Support for this can be seen in the correlation coefficients derived for each specific relation.

A value of 0.99 is recorded for the channel width-discharge relations; 0.95 is recorded for the channel and 0.90 for channel velocity-discharge relations. All these values are found significant at 0.01 confidence level; and their respective coefficients of determination $r^{2}$ are $98 \%$ for width-discharge, $90.25 \%$ for depth-discharge and $81 \%$ for velocity-discharge relations.

Water discharge in the Sombreiro River does indeed have a profound influence on the morphologic parameters of the channel (Fig. 3). In this river system, both the width and depth vary rapidly as the discharge increases downstream. By contrast, the river velocity indicates a slight downstream decrease as it flows into the heart of the Niger Delta basin.

It may therefore follow that geology as a contributory factor to channel velocity and sediment load may be of greater importance than previously thought as rivers that rise and flow within the same geological area tend to conform more to fluvial theoretical postulates as observed in the Sombreiro.

\section{The New Calabar Channel}

For the New Calabar River, the following channel geometric relations were observed;

$$
\mathrm{W}=3.98 \mathrm{Q}^{0.59}
$$
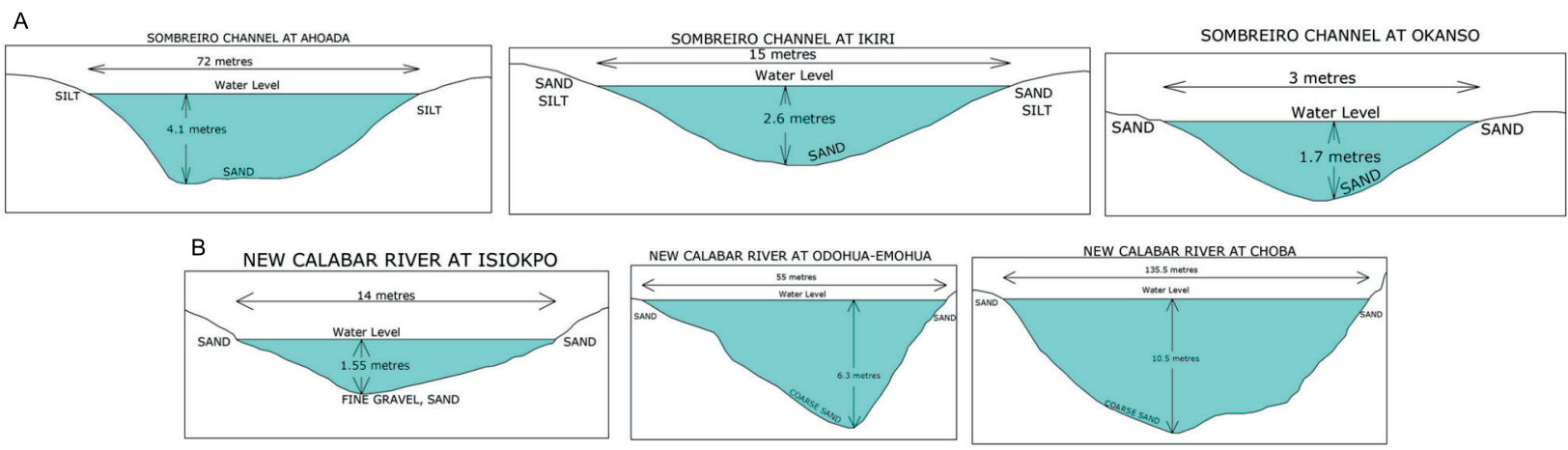

Fig. 3A. I, II and III: typical cross-sectional profiles of the Sombreiro River

Fig. 3B. I, II and III: typical cross-sectional profiles of the New Calabar River 


$$
\begin{aligned}
& \mathrm{d}=0.52 \mathrm{Q}^{0.47} \\
& \mathrm{v}=0.49 \mathrm{Q}^{-0.05}
\end{aligned}
$$

The relationships (Fig. 5) are direct and have a high parity of power exponents for width and depth indicating a fairly stable and uniform change in morphologic variables in the downstream direction. It should be noted that the New Calabar River was subject to tidal influence upstream of Choba town leading to reductions in downstream velocity.

The channel also has a large discharge from the catchment (490 cumecs at Choba 1) despite its relatively small size leading to scouring of river bed and banks thereby deepening and widening the channel thereof. Since the channel morphologic variables interact with each other apart from their interaction with discharge, velocity therefore changes less rapidly for the river (Morisawa 1968 1976). This accounts for the observed relationship in the New Calabar's velocity-discharge relation (Fig. 5).

The exponents of the equations for the morphology-discharge relations (Table 3 ) satisfy the continuity principle $(0.59+0.47+(-0.05)=1.0)$. The numerical constants, when multiplied yield 0.96 , a value close enough to the theoretical 1.0 , ie: $(3.98 \times 0.52 \times 0.49=1.0)$.

As suggested above, the morphologic variables of the New Calabar do not adjust well to the hydrologic regimen of the river. Evidence for this is seen further in the correlation coefficients for each of the relations. Channel width-discharge relations have a $r$ value of 0.74 with a coefficient of determination $\left(r^{2}\right)$ of $54.76 \%$. This means that only $54.76 \%$ of the variations observed in the river width is explained by variation in river water discharge.

Schumm (1968) concluded that adding the $M$ value (percent silt + clay in the channel perimeter) to discharge index, explains up to $87 \%$ of variation in bankfull width of the channels he studied for instance, the following relation:

$$
\mathrm{W}=370 \mathrm{Q}^{0.38} * \mathrm{M}^{0.39}
$$

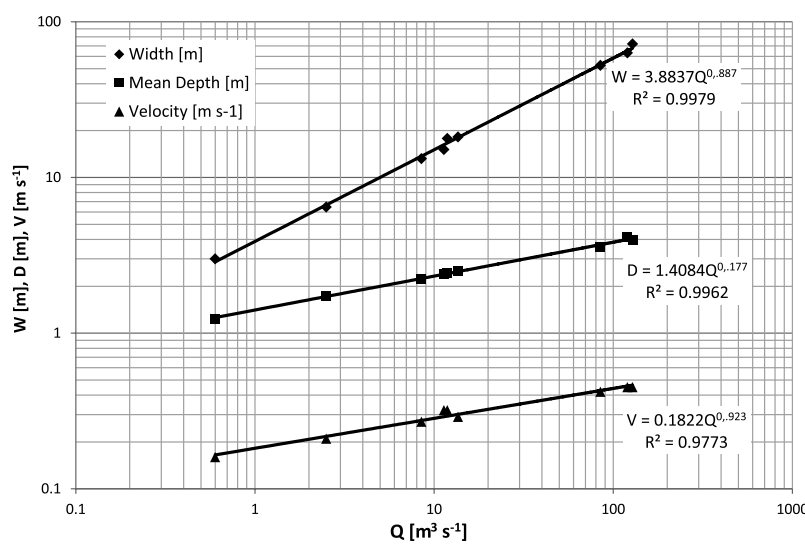

Fig. 4. Channel width $\mathrm{W}$ - discharge $\mathrm{Q}$, channel depth $\mathrm{D}$ - discharge Q and channel velocity $\mathrm{V}$ - discharge Q relationships of the Sombreiro River
In the New Calabar, greater explanation of the morphologic variation may be provided by the $\mathrm{M}$ index of the channel perimeter. To verify this, a multiple correlation coefficient was calculated for width with discharge and $\mathrm{M}$ (percent silt + clay). The $r^{2}$ value increased to $82 \%$ up from $54.16 \%$ for discharge alone.

It is of note too, that thet test of the $r$ value for width-discharge relation indicates that no significant relationship exist between width and discharge in the New Calabar River at the 0.1 confidence level, although significant relationship exists at the 0.5 confidence level.The depth-discharge relation records a high correlation value of 0.93 suggesting a more rapid adjustment in channel depth with increasing discharge, than in width.

The New Calabar River in fact, accommodates ocean-going vessels as far upstream as Choba, thus confirming proportionately higher changes in depth than width in the New Calabar River. Channel velocity-discharge relations record a dismal low correlation value (0.03). This value clearly indicates that velocity changes little in a downstream direction, as does discharge, in the New Calabar (Fig. 4). Significance tests with $t$ statistic show that New Calabar River's depth-discharge relation is significant at the $90 \%$ level, while the velocity-discharge relation is found not significant.

Table 3 presents a summary of the exponents and contents for the hydraulic geometry of the rivers as determined from field investigations, on the basis of the exponents $(b$, $f, m)$ and constants $(a, c, k)$. Williams, (1978) graphically computed hydraulic exponents for 165 streams across the United States, representing many physiographic regions, resulting in exponent ranges of $0.00<b<0.82,0.10<f$ $<0.78$ and $0.03<m<0.81$. Mackey et al. (1998) derived mean at-a-station exponents of $b=0.16, f=0.30$, and $m$ $=0.55$ for 24 river sites in Massachusetts as part of a hydraulic_geometry investigation. Emmett (1975) derived at-a-station curves for 39 sites in the upper Salmon River area in Idaho as part of a hydrologic evaluation of the area. The resulting mean at-a-station exponent values were $b=$ $0.14, f=0.40$, and $m=0.46$. Leopold and Maddock (1953) derived mean exponent values of $b=0.26, f=0.40$, and

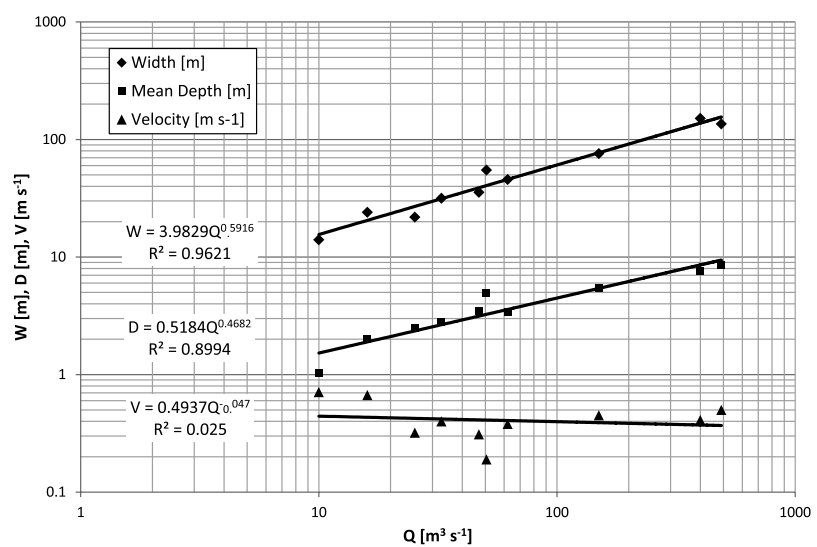

Fig. 5. Channel width $\mathrm{W}$ - discharge Q, channel depth $\mathrm{D}$ - discharge $\mathrm{Q}$ and channel velocity $\mathrm{V}$ - discharge $\mathrm{Q}$ relationships of the New Calabar River 
Table 3. Coefficients and exponents for the hydraulic-geometry equations for the Sombreiro and New Calabar rivers

\begin{tabular}{lcccccccc}
\hline \multirow{2}{*}{ River } & \multicolumn{3}{c}{ Exponents } & \multicolumn{3}{c}{ Coefficients } & \multicolumn{3}{c}{ Total } \\
\cline { 2 - 9 } & $b$ & $f$ & $m$ & $a$ & $c$ & $k$ & $b+f+m$ & $a^{*} c^{* k}$ \\
\hline Sombreiro & 0.59 & 0.22 & 0.19 & 3.88 & 1.41 & 0.18 & 1.0 & 1.0 \\
New Calabar & 0.59 & 0.47 & -0.05 & 3.98 & 0.52 & 0.49 & 1.0 & 1.0 \\
\hline
\end{tabular}

$m=0.34$ for 20 semiarid river sites in the Great Plains and south-western United States (Dudley 2004). From the values (in Table 3), it can be concluded that the hydraulic geometry relations of this two tropical deltaic catchments differ markedly from those derived for other regions.

\section{Width/Depth-Discharge Relations}

It has been shown that the width to depth ratio is largely a function of the cohesiveness of the material in which the stream flows. Ritter (1986) stated, based on Schumm's (1960) work that the channel shape is in a large part a function of the sediment in the channel perimeter. The relation is given as:

$$
\mathrm{F}=255 \mathrm{M}^{-1.08}
$$

where $\mathrm{F}$ is the width to depth ratio, and $\mathrm{M}$ is the percent of silt and clay in the channel perimeter. These width/depth-discharge relations are as follows:

For the Sombreiro:

$$
\mathrm{F}=8.11 \mathrm{Q}^{0.15}
$$

For the New Calabar:

$$
\mathrm{F}=11.85 \mathrm{Q}^{0.01}
$$

The $r$ value for the Sombreiro is 0.97 and $r^{2}=94 \%$. For the New Calabar $r=0.79$ and $r^{2}=62.4 \%$. All these values were found significantly related when tested with the students' $t$ test at the 0.01 confidence level. The high values of coefficients of determination also indicate that much of the downstream variation in the ratio $\mathrm{F}$ can be accounted for by changes in discharge.

Also in this study the width/depth ratio $\mathrm{F}$ was found to be related to the percentage of silt + clay $(\mathrm{M})$ in channel perimeter, according to the following least squares equations: For the Sombreiro:

$$
\mathrm{F}=-1.95 \mathrm{M}^{2.03},\left(r=-0.57, r^{2}=32 \%\right)
$$

For the New Calabar:

$$
\mathrm{F}=1.59 \mathrm{M}^{-1.7},\left(r=-0.51, r^{2}=26 \%\right)
$$

The parameter $\mathrm{M}$ is a measure of the resistance of the channel material to erosion. The higher the value of $\mathrm{M}$, the higher will be the resistance (Schumm 1977). The generally low degrees of explanation afforded by the results above indicate that the percentage of silt + clay (M) in the channel perimeter of these catchments do not exert any strong influence on channel morphologic changes $\mathrm{F}$ in a downstream directions. Table 4 and 5 presents the $\mathrm{M}$ values for the two channels studied.

The students' $t$ statistic was used to test the difference in the mean value of $\mathrm{M}$ in each of the catchments. This was in order to verify whether the noted differences in channel $M$ values, was actually significant. The $M$ values of the Sombreiro and New Calabar rivers are found significantly different at the 0.01 level.

\section{Water and Solute Dynamics in Channels}

Conductivity of the two rivers ranged between 11 and 16 $\mu \Omega \mathrm{cm}^{-1}$ for the Sombreiro and between 13 and $20 \mu \Omega$ $\mathrm{cm}^{-1}$ for the New Calabar, with the only aberrant case being the sample from Odohua (New Calabar River) where $50 \mu \Omega \mathrm{cm}^{-1}$ was recorded. This area of the river is suspected to have been contaminated by effluents from nearby residences. The generally small range of values however is strongly suggestive of a similar degree of chemical erosion in the channels. Comparison of results from the two catchments using the student's $t$ tests showed no significant differences exist between the TDS values (Table 4 and 5) of the rivers. From TDS results we infer that the two rivers carry similar kinds and comparable quantities of dissolved loads.

\section{Discharge of Suspended and Solute Sediment}

Table 6 illustrates the concentrations and the sediment discharge rates. By virtue of its high discharge rate, the New Calabar River at its catchment mouth at Choba, recorded the highest sediment discharge rate $\left(0.245 \mathrm{kgs}^{-1}\right)$. This is followed by the Sombreiro at Ahoada. This research being essentially a space-time integrated approach of fluvial processes in a downstream direction did construct sediment rating bivariate curves. Such curves are time-dependent and involve at-a-station measurements and analyses of repeatedly sampled river water.

\section{Sediments and Denudation Rates}

Mean annual denudation rates are usually estimated by the flow duration - sediment discharge method (Douglas 1968, Anderson 1972). Denudation rate in this study was determined following the method outlined in Gregory and Walling (1973):

Denudation in $\mathrm{m}^{3} \mathrm{~km}^{-2} \mathrm{yr}^{-1}=$ total load $(\mathrm{t}) /$ area $\left(\mathrm{km}^{2}\right) *$ specific gravity 
Table 4. Values of M (Percent Silt + Clay), conductivity of water samples SEC, and computed Total Dissolved Solids (TDS) from conductivity of water sample for Sombreiro River

\begin{tabular}{cccc}
\hline \multirow{2}{*}{ Sample } & $\mathrm{M}$ & $\mathrm{SEC}$ & $\mathrm{TDS}$ \\
\cline { 2 - 4 } & {$[\%]$} & {$\left[\mu \Omega \mathrm{cm}^{-1}\right]$} & {$\left[\mathrm{mg} \mathrm{L}^{-1}\right]$} \\
\hline 1 & 2.9 & 15.2 & 9.88 \\
2 & 3.4 & 15.0 & 9.75 \\
3 & 5.1 & 15.6 & 10.14 \\
4 & 6.2 & 15.6 & 10.11 \\
5 & 5.8 & 15.5 & 10.04 \\
6 & 2.8 & 16.0 & 10.41 \\
7 & 6.5 & 12.2 & 7.93 \\
8 & 6.7 & 10.6 & 6.89 \\
9 & 5.8 & 10.9 & 7.08 \\
10 & 6.3 & 11.7 & 7.60 \\
\hline
\end{tabular}

Denudation rates were estimated using the specific gravity of 1.0 (Walling 1971, Jeje et al. 1982) while total load of sediment yield was estimated from values of suspended and dissolved sediments (Cryer et al. 1981). The following values were derived as the denudation rates for the catchments:

For the Sombreiro: $\frac{1229.904}{484.0^{*} 1}=2.54 \mathrm{~m}^{3} \mathrm{~km}^{-2} \mathrm{yr}^{-1}$

For the New Calabar: $\frac{7726.32}{208 * 1}=37.15 \mathrm{~m}^{3} \mathrm{~km}^{-2} \mathrm{yr}^{-1}$

A marked difference may be noted in the erosion rate of the two catchments. The 37.15 cubic meters derived for the New Calabar is comparable to the 36.0 cubic meters derived by Lam (1978) for similarly forested catchments in Hong Kong while values for the Sombreiro are more comparable to other parts of Nigeria. The values of 2.16 derived by Jeje and Nabegu (1982) in the Amafa catchment in the Ife area of south-western Nigeria are also comparable to the 2.54, yielded by Sombreiro in this study.

The New Calabar's high rates may be accounted for by its relatively small sizes, loose deltaic unconsolidated sediment environments, relatively large discharge outputs and serious urban encroachment and development due to the expansion of the adjoining city of Port Harcourt and the expanding University of Port Harcourt community and facilities.

\section{Sediment Analysis}

Inclusive graphic mean measures of the bed load and river bank sediment is presented in table 7. Sediments from the catchments were not found to be significantly different at
Table 5. Values of M (Percent Silt + Clay), conductivity of water samples SEC, and computed Total Dissolved Solids (TDS) from conductivity of water sample for New Calabar River

\begin{tabular}{cccc}
\hline \multirow{2}{*}{ Sample } & $\mathrm{M}$ & $\mathrm{SEC}$ & $\mathrm{TDS}$ \\
\cline { 2 - 4 } & {$[\%]$} & {$\left[\mu \Omega \mathrm{cm}^{-1}\right]$} & {$\left[\mathrm{mg} \mathrm{L}^{-1}\right]$} \\
\hline 1 & 0.84 & 20.0 & 13.00 \\
2 & 0.98 & 19.5 & 12.67 \\
3 & 1.06 & 16.5 & 8.45 \\
4 & 3.42 & 50.0 & 10.72 \\
5 & 3.35 & 16.5 & 10.72 \\
6 & 1.20 & 15.3 & 9.91 \\
7 & 1.26 & 13.0 & 9.25 \\
8 & 1.35 & 14.2 & 32.50 \\
9 & 1.40 & 13.1 & 8.51 \\
10 & 1.40 & 15.0 & 9.75 \\
\hline
\end{tabular}

Table 6. Computed values of Sediment Discharge Rates

\begin{tabular}{lcc}
\hline \multicolumn{1}{c}{ Location } & $\begin{array}{c}\text { Concentrations } \\
\text { of Dissolved and } \\
\text { Suspended Solids }\end{array}$ & $\begin{array}{c}\text { Sediment } \\
\text { Load }\end{array}$ \\
\cline { 2 - 3 }$\left[\mathrm{g} \mathrm{L}^{-1}\right]$ & {$\left[\mathrm{kg} \mathrm{s}^{-1}\right]$} \\
\hline New Calabar at Odohua & 0.50 & 0.925 \\
New Calabar at Isiokpo & 0.26 & 0.003 \\
New calabar at Choba & 0.50 & 0.245 \\
Sombreiro at Okansu & 0.36 & 0.002 \\
Sombreiro at Ikiri & 0.35 & 0.004 \\
Sombreiro at Ahoada & 0.30 & 0.039 \\
\hline
\end{tabular}

95\% confidence level although significance is recorded at the $90 \%$ level confidence. The New Calabar has a poorly sorted symmetrically bimodal sediment distribution, while the Sombreiro bedload is moderately sorted while its river bank sediment is also poorly sorted. From table 7, it can be seen that the Sombreiro River has a negatively skewed value for their bed load and river bank sediments indicating an admixture of medium and fine sediments in the catchments with either masochistic or leptokurtic measure of central tendency in these sediments.

\section{Conclusion and recommendation}

The fundamental relations between channel-geometry dimensions, velocity, and flow can be expressed as power functions describing downstream hydraulic-geometry relations. This study shows that the studied catchments adjust their geometry to changing discharges. High values of coefficients of determination indicate a positive relationship between downstream variation in channel width to depth ratio and discharge.

Table 7. Inclusive Graphic Measures in Phi Units [ø]

\begin{tabular}{lccccc}
\hline \multicolumn{1}{c}{ River } & Mean & Median & Sorting & Skewness & Kurtosis \\
\hline I. Bedload & \multicolumn{7}{c}{ Sombreiro River } & & & \\
II. River bank sediments & 1.28 & 1.28 & 0.89 & -0.02 & 1.54 \\
\hline & 2.14 & 2.38 & 1.71 & -0.20 & 1.18 \\
\hline I. Bedload & \multicolumn{7}{c}{ New Calabar River } \\
II. River bank sediments & 0.55 & 0.72 & 1.29 & -0.24 & 1.16 \\
\hline
\end{tabular}


Also in this study the width/depth ratio (F) was found to be related to the percentage of silt + clay $(\mathrm{M})$ in channel perimeter. This downstream hydraulic-geometry relations are in general agreement with previously published hydraulic and channel adjustment data. Also among the two catchments studied, the Sombreiro has the highest $M$ values, and the only positive exponential relationship with width/depth ratio. This means there is a general downstream increase in the river's $M$ value, thus suggesting that it possesses the least erodible channel perimeter. This river has a tendency to overflow its bankfull stage during high flows, since scouring the channel bed and bank gets increasingly difficult downstream. This phenomenon was markedly observed throughout the length of the channel during the fieldwork on the river.

The New Calabar is also unique in that although, it has a small catchment, it has larger discharge figures and channel morphology parameters. It also is distinct in that it has two main first order streams that obtain their source from two distinct physiographic settings; one branch from swamp basins, the other from initially heavily forested coastal plains. Sediments transported as bed load therefore are bound to be markedly bimodal. In addition, not enough distance has been covered for them to get well sorted or broken down into smaller sizes, thus ensuring the bimodality and consequent poor sorting.

It can be concluded that the hydraulic geometry relations of this two tropical deltaic catchments differ markedly from those derived for other regions therefore illustrating the power of geology, physiography and climate in river behaviour.

\section{Acknowledgment}

Authors are grateful to anonymous reviewers for valuable comments to preliminary version of paper.

\section{References}

Alexander J.S., Zelt R.B., Schaepe N.J., 2009. Geomorphic Segmentation, Hydraulic Geometry, and Hydraulic Microhabitats of the Niobrara River, Nebraska - Methods and Initial Results. US Geological Survey 1-1-2009.

Anderson H.W., 1972. Major Floods, Poor Land use /delay return of Sedimentation to Normal Rates. United State Department of Agriculture Research Note PSW - 268.

ASTM International - Standards Worldwide. 2006. Standard Test Method for Sieve Analysis of Fine and Coarse Aggregates: C-136-06. ASTM, PA. USA.

Azeez L.O., 1971. Review of the Stratigraphy, Sedimentation and Structure of the Niger Delta. In: C.A.Kogbe (ed.), Geology of Nigeria. Elizabethan. Lagos: 259-272.

Bawa N., Jyani V., Tyagi P., Jain V., Shekhar S., 2012. Morphological Variability in the Yamuna River System and Role of Stream Power Distribution Pattern. IGCP Annual Meeting and Conference on Tropical Rivers: Hydro-Physical Processes, Impacts, Hazards and Management. IGCP 582: IIT Kanpur.

Cryer R., Trudgill S.T., 1981 Solutes. In: A.S.Goudie (ed.), Geomorphological Techniques. George Allen and Unwin, London: 181-195.

Douglas I., 1968. Erosion in the Sungei Gombak Catchment, Selangor. Malaysia Journal of Tropical Geography 26: 1-16.
Dudley R.W., 2004. Hydraulic-Geometry Relations for Rivers in Coastal and Central Maine. USGS Scientific Investigations Report 2004-5042) U.S. Geological Survey, Augusta, Maine.

Dury G.H., 1963. Rivers in Geographical Teaching Processes. Geography 6(3): 48-55.

Emmett W.W., 1975. The channels and waters of the Upper Salmon River area, Idaho: U.S. Geological Survey Professional Paper 870-A.

Ezekiel E.N, Hart A.I., Abowei J.F.N., 2011. The Physical and Chemical Condition of Sombreiro River, Niger Delta, Nigeria. Research Journal of Environmental and Earth Sciences 3(4): 327-340.

Faniran A., 1986. African Landforms: An introduction to Geomorphology. Heinemann Books Ltd. Ibadan.

Folk R.L., Ward W.C., 1957. Brazos River Bar: a Study in the Significance of Grain Size Parameters. Journal of Sedimentary Petrology 27: 3-26.

Golitzen K.G. (ed.), 2005. The Niger River Basin: A Vision for Sustainable Management. Directions in Development 34518. The World Bank, Washington DC.

Goudie A.S., 1981. Geomorphological Techniques. George Allen and Unwin.

Gregory K.J., Wailing D.E., 1973. Drainage Basin form and Process: a Geomorphological Approach. Arnold, London.

Jeje L.K., Nabegu A., 1982. Sediment Yield in Response to Rainstorms and Land use in Small Drainage Basins in Ife Area of Southwestern Nigeria. Nigerian Geographical Journal 25(1 and 2): 87-103.

Jorgensen D.G., 2003.The Missouri River below Gavins Point- the Least Terns, Piping Plovers, Sandbars, and the Natural Hydrograph.The Missouri River Technical Committee of the Siouxland Chamber of Commerce.

King C.A.M., 1966. Techniques in Geomorphology. Arnold, London.

Lam K.C., 1978. Soil Erosion, Suspended Sediment and Solute Production in Three Hong Kong Catchments. Journal of Tropical Geography, Geography 47: 51-62.

Langbein W.B., 1962. The concept of entropy in Landscape Evolution. U.S. Geological Survey Professional Paper. 500-A.

Leopold L.B., Maddock T., Jr., 1953. The hydraulic geometry of stream channels and some physiographic implications: U.S. Geological Survey Professional Paper 252, $57 \mathrm{p}$.

Leopold L.B., Wolman, M.G., Miller J.P., 1964. Fluvial Processes in. Geomorphology. W.H. Freeman and Company, New York.

Leys K 1997. Rivers and their catchments: channel form and processes. Information and Advsiory Note Number 79, March 1997. Scottish Natural Heritage. Online: www.snh.org.uk/publications/on-line/advisorynotes/79/79.html.

Mackey P., Barlow P.M., Ries K.G., III. 1998. Relations between discharge and wetted perimeter and other hydraulic-geometry characteristics at selected streamflow-gaging stations in Massachusetts: U.S. Geological Survey Water-Resources Investigations Report 98-4094.

Martinez F.B, Mijares M.B.B, Galera I.C., 2011. Assessment of the Water Quality of Mamba River of Mts. Palaypalay/Mataas na Gulod, Southern Luzon, Philippines 2011 International Conference on Chemistry and Chemical Process IPCBEE 10.

Morisawa M.E., 1968. Streams: their Dynamics and Morphology McGraw-Hill, New York.

Morisawa M. E. 1976. Geomorphology Laboratory Manual. John Wiley, New York.

NEDECO [Netherlands Engineering Consultants], 1961. River Studies: The Waters of the Niger Delta. The Hague.

O'Connora J.E, Myrtle A.J., Haluska T.L., 2003. Flood plain and channel dynamics of the Quinault and Queets Rivers, Washington, USA. Geomorphology 51: 31-59.

Ofomata G.E.K., 1974. Trends in Geomorphology and their Relevance to School Geography. Bulletin, Ghana Geographical Association 16: 16-26.

Park C.C., 1977. World-wide variations in hydraulic geometry exponents of stream channels - an analysis and some observations: Journal of Hydrology 33: 133-146.

Parker G., Wilcock P.R., Paola C., Dietrich W.E., Pitlick J., 2007. Physical basis for quasi-universal relations describing bankfull hydraulic geometry of single-thread gravel bed rivers. Journal of Geophysical Research 112: $21 \mathrm{p}$.

Parker G., 1979. Hydraulic geometry of active gravel rivers. Journal of the Hydraulics Division 109(1): 185-1201. 
Ritter D.F., 1986. Process geomorphology. W.C.Brown Publishers.

Rosgen D.L., 1994. A classification of natural rivers. Catena 22: 169199.

Short K.C., Stauble A.J., 1967. Outline of the Geology of the Niger Delta. American Association of Petroleum Geologists, Bulletin 51: 761-779.

Simon A., Castro J., 2003. Measurement and analysis of alluvial channel form. In: G.E.Kondolf, H.Piegay (eds), Tools in fluvial geomorphology. John Wiley and Sons, Chichester: 291-322.

Tandon S.K., 2012. Living with 'disturbed' large river systems: Securing river futures with River Science. IGCP Annual Meeting and Confe- rence on Tropical Rivers: Hydro-Physical Processes, Impacts, Hazards and Management. IGCP 582: IIT Kanpur.

Thornes J.B., 1979. Fluvial Processes. In: C.Embleton, Thornes J. (eds), Process in Geomorphology, Arnold, London.

Williams G.P., 1978, Hydraulic-geometry of river cross sections - Theory of minimum variance. U.S. Geological Survey Professional Paper $1029,47 \mathrm{p}$.

Wolman M.G., 1955. The Natural Channel of Brandywine Creek Pennsylvania. U.S. Geological Survey Professional Paper 271. 